\title{
AN EMPIRICAL ANALYSIS OF CORRELATION BETWEEN THE THICKNESS OF A THERMAL INSULATION LAYER OF THE FLOOR AND THE PAYBACK PERIOD
}

\author{
Donatas AVIZA a,b, Zenonas TURSKIS ${ }^{\mathrm{b}}$ \\ ${ }^{a}$ Department of Civil Engineering, Faculty of Technologies, Kaunas University of Technologies, \\ Panevežys Institute, S. Daukanto g. 12-138, 35212 Panevėžys, Lithuania \\ ${ }^{b}$ Department of Construction Technology and Management, Vilnius Gediminas Technical University, \\ Saulètekio al. 11, 10223 Vilnius, Lithuania
}

Received 31 Dec 2012; accepted 16 Oct 2013

\begin{abstract}
The article provides the correlation analysis between the thickness of a thermo-insulation layer of the typical floor-on-soil sample and its simple payback time in a traditional new construction single-apartment residential and net-zero energy building. The calculations were carried out on the energy efficiency class of the building and the geographic area of the construction. On the basis of the results, a simple payback time was calculated. The main aim thermal transmittance coefficients of soil touching partitions must satisfy the normative value of technical construction regulation and European standards. The research object of the study is relationships between the thickness of a thermoinsulation layer of the typical floor-on-soil sample and its simple payback time. Lithuania was chosen as the geographic area of the research. Calculations were carried out for seven towns: Vilnius, Kaunas, Klaipeda, Siauliai, Panevezys, Utena, and Dukstas. The test result - developed correlation functions. Correlation analysis results are important not only for designers making decisions during the pre-design stage, but also for energy consumption auditors and experts.
\end{abstract}

Keywords: residential building, thermo-insulation thicknesses, payback period, energy performance, correlation analysis, geographic area.

\section{Introduction}

By 31 December 2020, European Union Member States must ensure that all newly constructed buildings are nearly zero-energy buildings conforming to requirements of the European Directive 2010/31/EU (2010). 8-year period is set to achieve this aim (Marszal et al. 2012).

Single-apartment residential buildings with almost no consumed energy are especially energy efficient as energy consumption is almost equal to zero or very low. Most of energy needs in such buildings are met using renewable energy resources, including production on site or in close proximity. In Lithuania, A++ class buildings correspond to this category.

Effective design and construction of buildings that consumes almost no energy (A++ class) is a big challenge for Lithuania as well as the entire Europe. There is limited experience and analysis of this problem. Therefore, many articles emphasise the existing need for a scientific stimulus in this direction (Kurnitski et al. 2011).

Consuming as much as $40 \%$ of the total amount of energy, the building sector has a large potential for energy savings (Kaynakli et al. 2012). Discussions on these issues are held on the international level. The United States of America adopted the energy-saving declaration (The Energy Independence and Security Act 2007), which establishes plans to reduce energy consumption in the building sector by 2030 , and fully implement the reforms by 2050 (Marszal et al. 2012).

Environmental and financial issues make energy consumption and management relevant for Asian region as well. In particular, the building sector of China is among the largest energy consumers. Up to 2006, approx. 40 billion sq. $\mathrm{m}$ of useful area has been constructed in China. The number of buildings continues to grow. In the period of 5-years, China aims to increase energy efficiency by $20 \%$ (Kong et al. 2012).

Increase of energy efficiency in the Lithuanian building sector is a big challenge as well. In order to achieve these objectives in time, i.e. pass from minimal energy efficiency requirements of class $\mathrm{C}$ to class $\mathrm{A}++$, it is important to rationally evaluate climate parameters and the influence of payback on final decisions.

This task is especially crucial in the sector of residential buildings. According to the data of Statistics

Corresponding author: Donatas Aviza

E-mail:donatas.aviza@dok.vgtu.lt 
Lithuania (2013), residential buildings amount to 55\% of the total floor area and exceed 100 million sq. $\mathrm{m}$. The total of 400 thousand single-apartment residential buildings and home gardens takes up approx. half of this area.

This study aims to create correlation functions and determinate the link between the thickness of a thermal insulation layer of the floor and it's simple payback time.

\section{Object description}

According to the currently valid normative requirements in Lithuania and provisions of STR 2.01.09:2012 "Energy performance of buildings" (2012). Certification of energy performance", buildings are classified into 9 energy efficiency classes: A++, A+, A, B, C, D, E, F, G (Fig. 1). Until 2014, the energy efficiency class of newly constructed buildings (building parts) must not be lower than "C".

In Lithuania, traditional single-apartment residential buildings are built and designed according to provisions of the technical construction regulation STR 2.01.09:2012 (2012), which means that often minimum requirements of " $\mathrm{C}$ " energy efficiency class are reached.

Starting with 2007, minimum requirements have been raising to transition to a more efficient energy consumption in buildings (Fig. 1).

Allocation of buildings according to energy efficiency classes are regulated by heat transfer coefficients of the external partition $\left(U_{N}, \mathrm{~W} /\left(\mathrm{m}^{2} \cdot \mathrm{K}\right)\right)$ and the specific heat loss $\left(H_{N}, \mathrm{~W} / \mathrm{K}\right)$, which also directly depends on the

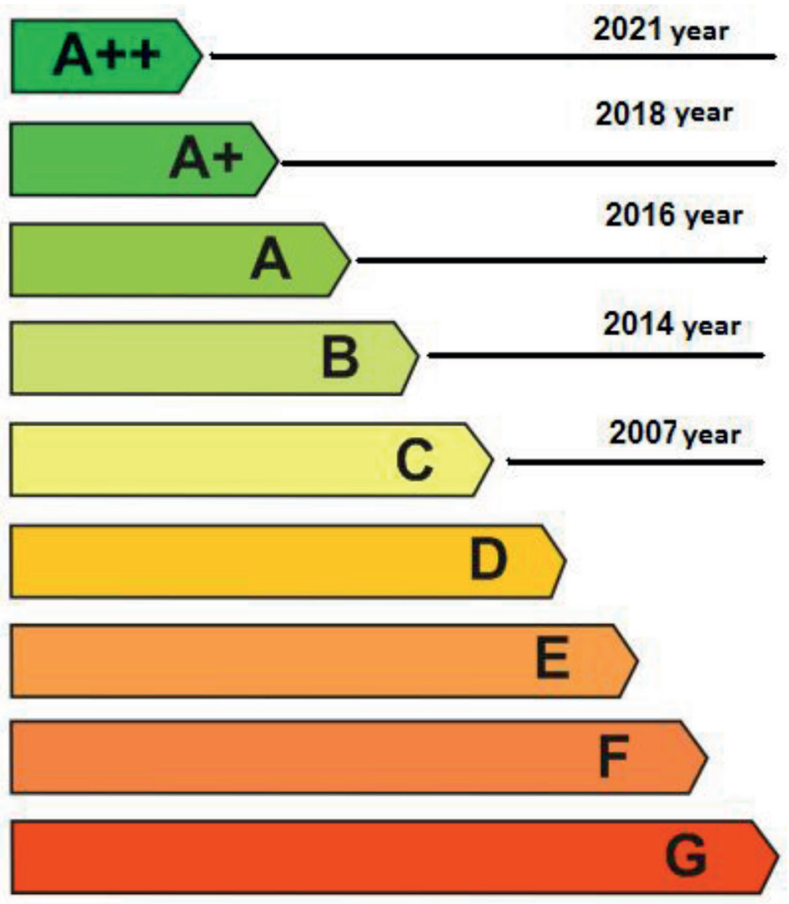

Fig. 1. Classification of energy efficiency of buildings. Class A++ indicates a highly energy-efficient building, Class G indicates an energy-inefficient building heat transfer coefficients. Normative requirements for partitions touching the soil of heated single-apartment residential buildings have been investigated in the study (Table 1).

This study aims to research the relationship between the thicknesses of a thermo-insulation layer of the flooron-soil and its simple payback time. The slab-on-ground floor was evenly insulated with expanded polystyrene (EPS100) foam, which has the declared value of thermal conductivity coefficient (in this study) amounting to $\lambda_{\text {dec }}=0.035 \mathrm{~W} /(\mathrm{m} \cdot \mathrm{K})$.

Aiming to ascertain the influence of climate and geographic location on the thickness of a thermoinsulation layer, calculations were made in seven characteristic Lithuanian cities. In this study, the average outdoor air temperature (Table 2) was taken based on requirements of the Norm on Construction of the Republic of Lithuania RSN 156-94 "Building climatology" (1994) (average data of 30 years).

The problem is that according to national normative energy efficiency documents, Lithuania is regarded as one climatic region, with the average outdoor air temperature of $+0.6^{\circ} \mathrm{C}$ during a heating season. Different climatic zones of Lithuania have different outdoor air temperature; therefore, using correlation dependence functions, calculation solution of thermo-insulation layer thickness of the typical floor-on-soil sample will be examined in this study.

Table 1. Normative value of the thermal transfer coefficient pertaining to partitions touching the soil in a single apartment residential buildings $\mathrm{U}_{N . f g}, \mathrm{~W} /\left(\mathrm{m}^{2} \cdot \mathrm{K}\right)$

\begin{tabular}{lcc}
\hline $\mathrm{Nr}$. & $\begin{array}{c}\text { Energy performance } \\
\text { class }\end{array}$ & $\mathrm{U}_{N \cdot f g}, \mathrm{~W} /\left(\mathrm{m}^{2} \cdot \mathrm{K}\right)$ \\
\hline 1 & $\mathrm{C}$ & $0.25 \cdot \mathrm{k}$ \\
\hline 2 & $\mathrm{~A}$ & $0.14 \cdot \mathrm{k}$ \\
\hline 3 & $\mathrm{~A}+$ & $0.12 \cdot \mathrm{k}$ \\
\hline 4 & $\mathrm{~A}++$ & $0.10 \cdot \mathrm{k}$ \\
\hline
\end{tabular}

The multiplier $\mathrm{k}=20 /\left(\theta_{i}-\theta_{e}\right)$, here $\theta_{i}-$ indoor temperature during heating season, shall be $\theta_{i}=20{ }^{\circ} \mathrm{C} ; \theta_{e}$ - the average outdoor air temperature during a heating season (Table 2).

Table 2. The average outdoor air temperature during a heating season and duration of the heating season in days

\begin{tabular}{lcc}
\hline \multirow{2}{*}{ Location } & \multicolumn{2}{c}{ A heating season start/end $<10{ }^{\circ} \mathrm{C}$} \\
\cline { 2 - 3 } & The average temperature, $\theta_{e},{ }^{\circ} \mathrm{C}$ & $\begin{array}{c}\text { Duration } \\
\text { in days }\end{array}$ \\
\hline Siauliai & 0.6 & 222 \\
\hline Panevezys & 0.4 & 218 \\
\hline Klaipeda & 1.9 & 214 \\
\hline Utena & 0.1 & 221 \\
\hline Dukstas & -0.3 & 223 \\
\hline Kaunas & 0.7 & 219 \\
\hline Vilnius & 0.2 & 225 \\
\hline Lithuania & 0.6 & 220 \\
\hline
\end{tabular}


The following part of the article addressed the calculation methodology of heat transfer coefficient pertaining to partitions touching soil; and correlation dependence of the thickness of a thermo-insulation layer on the energy performance class and type of the geographic location of a building. Next, the obtained results are used to calculate a simple payback time.

\section{Calculation methodology}

In this study, general data and general formulas for partitions touching soil were taken from the documents STR 2.05.01:2005 "Thermal Technologies of Partitions of a Building" (2005) and EN ISO 13370:2008 "Thermal Performance of Buildings - Heat Transfer via the Ground - Calculation Methods" (2008).

The methodology is based on thermal transmittance coefficient of floor-on-soil (Fig. 2) insulated at edges U $\left(\mathrm{W} /\left(\mathrm{m}^{2} \cdot \mathrm{K}\right)\right)$ calculation:

$$
U_{f g}=U_{0}+\frac{2 \cdot \Delta \Psi}{B^{\prime}}
$$

where: $U_{0}$ is the component of the thermal transmittance coefficient of floor-on-soil depending on floor, area, perimeter and thickness of walls surrounding the floor $\left(\mathrm{W} /\left(\mathrm{m}^{2} \cdot \mathrm{K}\right) ; \Delta \Psi\right.$ is correction, which includes the influence of insulation of edges. Calculated using Eqn (8); $B^{\prime}$ is the value of the characteristic floor dimension (m), calculated as follows:

$$
B^{\prime}=\frac{A}{0.5 \cdot P},
$$

where: $A$ - the area of floor on soil $\left(\mathrm{m}^{2}\right) ; P$ - the perimeter of floor $(\mathrm{m})$.

The values of variables $A$ and $P$ can be calculated using the internal dimensions of a building.

$U_{0}\left(\mathrm{~W} /\left(\mathrm{m}^{2} \cdot \mathrm{K}\right)\right)$ value calculated using the equations:

a) if a floor is non-insulated or minimally insulated $\left(d_{t}<B^{\prime}\right)$, then:

$$
U_{0}=\frac{2 \lambda_{g r}}{\pi B^{\prime}+d_{t}} \ln \left(\frac{\pi \cdot B^{\prime}}{d_{t}}+1\right)
$$

b) if a floor is well insulated $\left(d_{t} \geq B^{\prime}\right)$, then:

$$
U_{0}=\frac{\lambda_{g r}}{0.457 \cdot B^{\prime}+d_{t}}
$$

where: $\lambda_{g r}$ is the thermal conductivity coefficient of soil $(\mathrm{W} /(\mathrm{m} \cdot \mathrm{K})) ; d_{t}$ - resultant thickness of the floor panel expressed in thickness of a soil layer (m):

$$
d_{t}=w+\lambda_{g r} \cdot\left(R_{s e}+R_{f}+R_{s i}\right),
$$

where: $w$ - thickness of the wall around the floor (m); $R_{f}$ - thermal resistance of a floor $\left(\mathrm{m}^{2} \cdot \mathrm{K} / \mathrm{W}\right) ; R_{s e}$ - thermal resistance of internal surface $\left(\mathrm{m}^{2} \cdot \mathrm{K} / \mathrm{W}\right) ; R_{s i}$ - thermal resistance of external surface $\left(\mathrm{m}^{2} \cdot \mathrm{K} / \mathrm{W}\right)$.
Additional thermal resistance of floor-on-soil calculated when vertical $R_{v \text {.ins }}^{\prime}\left(\mathrm{m}^{2} \cdot \mathrm{K} / \mathrm{W}\right)$ insulation at edges is present:

$$
R_{v . i n s}^{\prime}=R_{v . \text { ins }}-\frac{d_{v, i n s}}{\lambda_{g r .}},
$$

where: $R_{v \text {.ins }}$ - thermal resistance of a vertical thermoinsulation layer at edges $\left(\mathrm{m}^{2} \cdot \mathrm{K} / \mathrm{W}\right) ; d_{\text {v.ins }}-$ thickness of vertical thermo-insulation layers at edges (m).

The resultant thickness of additional insulating layer (expressed by thickness of a soil layer) calculated when vertical $d_{v}^{\prime}(\mathrm{m})$ insulation at edges is present:

$$
d^{\prime}{ }_{v}=R_{v \text {.ins }}^{\prime} \cdot \lambda_{g r}
$$

When a thermo-insulation layer is vertical along the perimeter of a building, inside or outside of the foundation (Fig. 2), the value of $\Delta \Psi$ can be calculated as follows:

$$
\Delta \Psi=-\frac{\lambda_{g r}}{\pi}\left[\ln \left(\frac{2 \cdot D_{v}}{d_{t}}+1\right)-\ln \left(\frac{2 \cdot D_{v}}{d_{t}+d^{\prime}{ }_{v}}+1\right)\right] .
$$

The main verification condition - the heat transfer coefficient of floor-on-soil must satisfy the normative requirements:

$$
\mathrm{U}_{f g} \leq \mathrm{U}_{N f f},
$$

where: $U_{f g}$ is the design heat transfer coefficient of floor on soil $\mathrm{W} /\left(\mathrm{m}^{2} \cdot \mathrm{K}\right)$, which directly depends on the investigation object, i.e. on thermo-insulation thickness (Fig. 3); $U_{N . f g}$ is normative heat transfer coefficient of floor-on-soil $\mathrm{W} /\left(\mathrm{m}^{2} \cdot \mathrm{K}\right)$, depending on the purpose of the building, energy efficiency class (Table 1) and the average outside air temperature during a heating season (Table 2).

When required thickness of the thermo-insulation layer is obtained, the simple (investment) payback time is calculated (Stankevičius et al. 1997):

$$
P S=\frac{I_{0}}{\Delta S},
$$

where: $I_{0}$ is the amount of investment to the additional insulation, $€ / \mathrm{m}^{2}$ (Table 6); $\Delta S$ is annual savings, first year cost, euro/( $\mathrm{m}^{2} \cdot$ years $)$.

The annual savings are calculated according to the following expression:

$$
\Delta S=\left(Q_{f g 2}-Q_{f g 2}\right) \cdot E,
$$

where: $Q_{f g 1}$ is the heat loss through building partitions touching soil without insulation, during a heating season, $\mathrm{kWh} /\left(\mathrm{m}^{2}\right.$.years $) ; Q_{f g 2}$ is the heat loss through building partitions touching soil with insulation, during a heating season $\mathrm{kWh} /\left(\mathrm{m}^{2} \cdot\right.$ years $) ; E$ is the heat energy costs, $€ / \mathrm{kWh}$.

In general, the heat loss is calculated according to the formula: 
$Q_{f g}=\frac{24 \cdot t}{1000} \cdot\left[H_{f g} \cdot\left(\bar{\theta}_{i}-\bar{\theta}_{e}\right)-\gamma \cdot H_{p i} \cdot \hat{\theta}_{i}+\gamma \cdot H_{p e} \cdot \hat{\theta}_{e}\right]$

where: $t$ is the duration of a heating season in days; $H_{f g}$ is the steady-state ground heat transfer coefficient, in $\mathrm{W} / \mathrm{K} ; H_{p i}$ is the internal periodic heat transfer coefficient, in $\mathrm{W} / \mathrm{K} ; H_{p e}$ is the external periodic heat transfer coefficient, in $\mathrm{W} / \mathrm{K} ; \bar{\theta}_{i}$ is the annual average internal temperature, in ${ }^{\circ} \mathrm{C} ; \bar{\theta}_{e}$ is the annual average external temperature, in ${ }^{\circ} \mathrm{C} ; \hat{\theta}_{i}$ is the amplitude of variations in monthly mean internal temperature, in $\mathrm{K}$; $\hat{\theta}_{e}$ is the amplitude of variations in monthly mean external temperature, in $\mathrm{K} ; \gamma$ is the coefficient, which depends on the duration of the heating season.

\section{The research model}

The research model has been created for determination of correlation functions, using the following building design solutions:

1. The area of floor-on-soil of a single-apartment residential building was accepted in calculations $A=155.5 \mathrm{~m}^{2}$ (the internal dimensions of the plan $10.00 \times 15.55 \mathrm{~m})$.

2. The value of periodic penetration depth of soil $\Omega(\mathrm{m})$ used in calculation $\Omega=2 \mathrm{~m}$. The thermal conductivity coefficient of soil used in all calculations $-l_{g r}=2 \mathrm{~W} /(\mathrm{m} \cdot \mathrm{K})$. Thickness of the wall around the floor $w=0.3 \mathrm{~m}$.

3 . The depth of a vertical thermal insulation layer $D_{v}=0.6 \mathrm{~m}$. Thickness of vertical thermal insulation layers at edges $d_{v \text {.ins }}=0.1 \mathrm{~m}$ (for class "C") $d_{v \text {.ins }}=$ $0.2 \mathrm{~m}$ (for classes "A").

4. The floor covering and separating layer was adopted as thin layer $R_{q 1}=0.02\left(\mathrm{~m}^{2} \times \mathrm{K}\right) / \mathrm{W}$ and $R_{q 3}=$ $0.04\left(\mathrm{~m}^{2} \times \mathrm{K}\right) / \mathrm{W}$ respectively, according to technical regulation of construction STR 2.05.01:2005 "Thermal Technologies of Partitions of a Building" (2005).

5. The expanded polystyrene (EPS100) foam was used for insulation according to ST 124555837.01:2005 "Thermal insulation of building partitions with

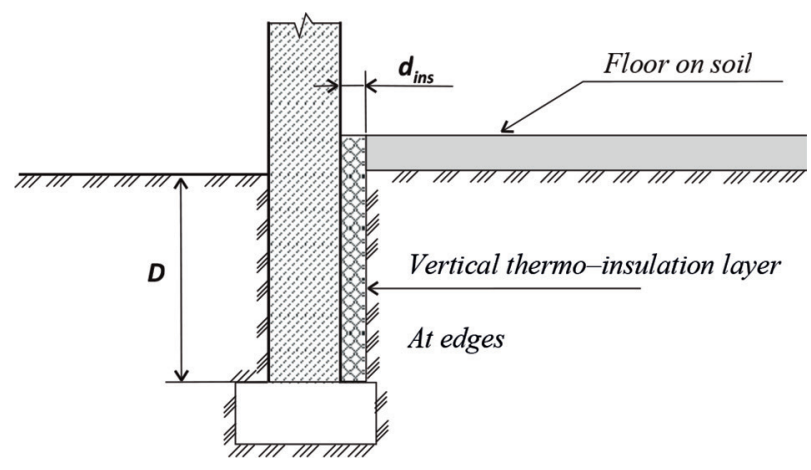

Fig. 2. Insulation diagram of floor-on-soil with vertical thermal insulation layer at edges expanded polystyrene foam" (2005) (Fig. 3). The value of heat conductivity coefficient $-l_{D}=0.035 \mathrm{~W} /(\mathrm{m} \cdot \mathrm{K})$. The design value of heat conductivity coefficient accepted: $0.041 \mathrm{~W} /(\mathrm{m} \cdot \mathrm{K})$ - for horizontal layer and $0.045 \mathrm{~W} /(\mathrm{m} \cdot \mathrm{K})$ - for vertical layer (according to document STR 2.01.03:2009 "Declared and Design Values of Thermal Technical Variables of Construction Materials and Products" (2009)).

6. Normative values of heat transfer coefficient of partitions touching soil were accepted according to requirements of technical construction regulation STR 2.01.09:2012 "Energy performance of buildings. Certification of energy performance" (2012), assessing temperature adjustment $k=20 /$ $\left(q_{I}-0.6\right)$, when $q_{I}=20{ }^{\circ} \mathrm{C}$. Regional - according to requirements of technical construction regulation STR 2.05.01:2005 "Thermal Technologies of Partitions of a Building" (2005), assessing temperature adjustment $k=20 /\left(q_{i}-q_{e}\right)$, when $q_{e}$ accepted in Table 2.

7. The reinforced concrete layer thickness was $60 \mathrm{~mm}$. The value of heat conductivity coefficient $l_{\mathrm{D}}=2.3 \mathrm{~W} /(\mathrm{m} \cdot \mathrm{K})$.

8. The price of insulation materials (EPS100) was 49.28 EUR $/ \mathrm{m}^{3}$.

9. Thermal energy cost was (the average price of central heating systems in 2011) $E=0.2484 \mathrm{LTL} /$ $\mathrm{kWh}(0.072 € / \mathrm{kWh})$.

Research calculations were performed using the same model/element (the same building design solutions),

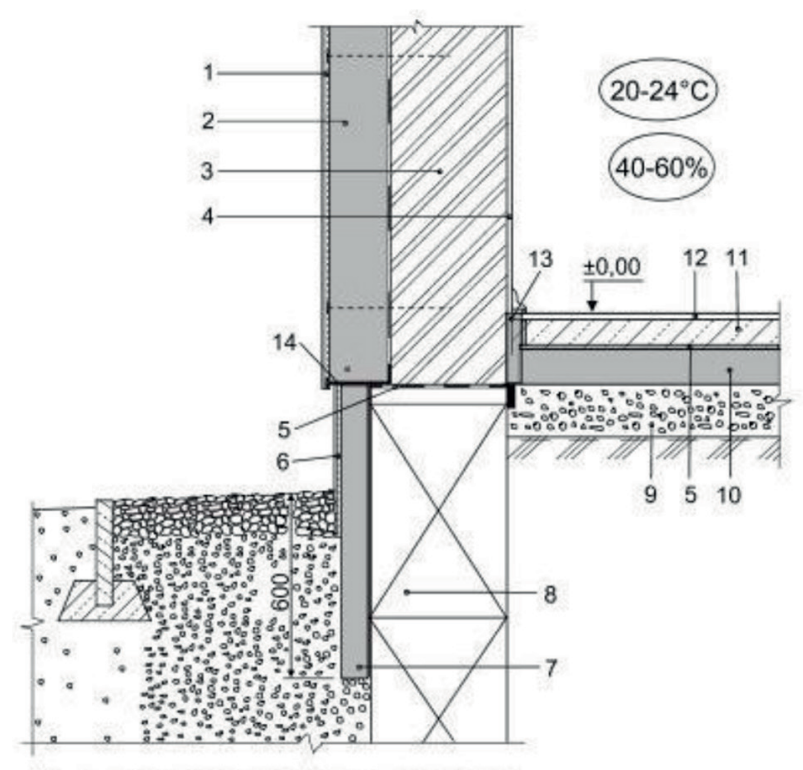

Fig. 3. Research object - thickness of horizontal thermal insulation layer of the floor-on-soil, $\mathrm{mm}$ (position - 10); 1 - thin rendering; 2 - thermal insulation; 3 - wall; 4 - surface finishing; 5 - horizontal waterproofing; 6 - plinth finishing; 7 - vertical thermal insulation; 8 - foundation; 9 - gravel layer; 10 - horizontal thermal insulation; 11 - concrete slab; 12 - floor covering 
changing only the construction geographical location and climatic data.

\section{The research results}

The required thickness of the thermal insulation layer of the typical floor-on-soil sample was calculated according to methodology of calculation of heat transfer coefficient of partitions touching soil and energy efficiency normative requirements for construction partitions. As provided in Table 5, the final thicknesses of the floor were calculated using the approximation method of checking the condition of Eqn (9) and changing climatic data.

The thickness of a thermal insulation layer increases proportionally with increasing energy efficiency class, when using traditional insulation materials (in this study - EPS100) for thermal insulation of partitions touching soil. The normative thickness of a thermal insulation layer increases 4 times for buildings with almost unconsumed energy (A++ class), compared with the currently valid minimum requirements pertaining to energy efficiency class "C", as shown in Table 5.

Qualitative parameters were estimated, for determining the correlation relationship between the building energy efficiency class and the thickness of a thermal insulation layer of partitions touching soil. In this study, only 4 energy performance classes ("C"; " $\mathrm{A}$ "; "A+" and "A++") were tested because only they have normative values for thermal transfer coefficients (Table 1). For this reason, energy performance class "C" was assigned 1 point; "A"-2 points; "A+" -3 points; "A++" -4 points (Table 3 ).

Polynomial regression function was used for justification of calculations, because this type of function has greater accuracy. The correlation and determination coefficient in all equations was obtained equal to unity $(R=+1)$, because there were just 4 points. This shows that there is an absolute direct and high-quality link between energy efficiency class and the thickness of a thermal insulation layer.

The research proved that Lithuania should not be regarded as one climatic zone. The currently valid energy efficiency calculation procedure is only suitable for Kaunas and Siauliai regions (Table 5) as they have equal normative requirement values. Therefore, the proposal is to have at least 3-5 climatic zones.

To preliminarily evaluate the quantities of required materials, designers, energy consumption auditors and experts have been recommended to calculate thermal insulation layer thickness of partitions touching soil

Table 3. Qualitative parameters

\begin{tabular}{ccc}
\hline No. & Energy performance class & $\begin{array}{c}\text { A qualitative parameter, } \\
x, \text { points }\end{array}$ \\
\hline 1 & $\mathrm{C}$ & 1 \\
\hline 2 & $\mathrm{~A}$ & 2 \\
\hline 3 & $\mathrm{~A}+$ & 3 \\
\hline 4 & $\mathrm{~A}++$ & 4 \\
\hline
\end{tabular}

Table 4. Required thickness of a thermal insulation layer $(y), \mathrm{mm}$

\begin{tabular}{clc}
\hline No. & Location & \multicolumn{1}{c}{ Correlation function $(\mathrm{y}), \mathrm{mm}$} \\
\hline 1 & Dukstas & $y=15 \cdot x^{3}-125 \cdot x^{2}+390 \cdot x-190$ \\
\hline 2 & $\begin{array}{l}\text { Vilnius and } \\
\text { Utena }\end{array}$ & $\mathrm{y}=15 \cdot x^{3}-125 \cdot x^{2}+390 \cdot x-200$ \\
\hline 3 & Panevezys & $y=13.33 \cdot x^{3}-115 \cdot x^{2}+371.67 \cdot x-190$ \\
\hline 4 & $\begin{array}{l}\text { Siauliai and } \\
\text { Kaunas }\end{array}$ & $y=13.33 \cdot x^{3}-110 \cdot x^{2}+346.67 \cdot x-170$ \\
\hline 5 & Klaipeda & $y=15 \cdot x^{3}-125 \cdot x^{2}+380 \cdot x-200$ \\
\hline $\begin{array}{l}\text { Normative } \\
\text { (Lithuania) }\end{array}$ & $y=13.33 \cdot x^{3}-110 \cdot x^{2}+346.67 \cdot x-170$ \\
\hline
\end{tabular}

here $x$ - Energy performance class, points (Table 3)

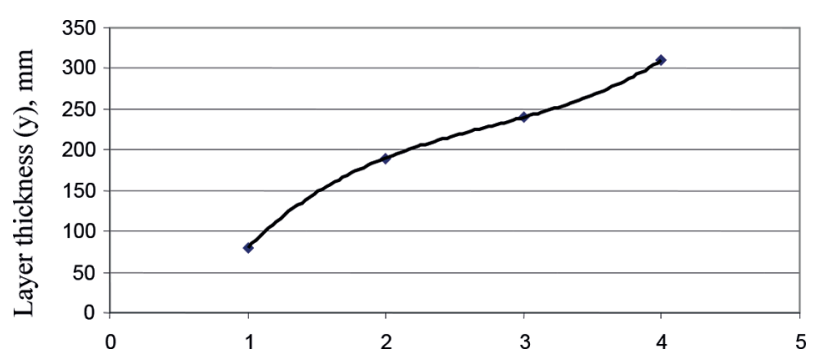

Fig. 4. The correlation analysis (normative value)

of single-apartment residential buildings according to obtained correlation relationship functions (Table 4 and Fig. 4).

Annual savings (Table 7) were calculated using the Eqn (11), subsequent to appropriate calculations regarding the thickness of a thermal insulation layer. It should be noted that it is very difficult/unreliable to provide the inflation, income/interest rates and heat cost levels over a long period under developing/changing economic conditions of a country (Stankevičius et al. 1997). Therefore, simple payback time was calculated in the paper (Table 8). Investigations demonstrated that there were no significant differences in calculating the payback time if Lithuania was divided into separate regions. Therefore, a common correlation relationship function (13) can be used for the entire Lithuania (normative requirement). Simple payback time $\left(y_{1}\right.$, years) was calculated using the created formula:

$$
y_{1}=0.3576 \cdot x^{3}-3.1174 \cdot x^{2}+9.3470 \cdot x-2.6252,(13)
$$

where, $x$ is energy efficiency class, points (Table 3 ).

\section{Conclusions}

1. The analysis shows that variation of the thickness of a thermal insulation layer of the typical floor-onsoil sample depends on the energy efficiency class and the type of geographical location. During the predesign stage, while selecting preliminarily quantities of required insulation materials for partitions touching soil for different regions of Lithuania, it 
Table 5. Calculated thickness of the thermal insulation layer (according to normative requirements)

\begin{tabular}{lcccccccccc}
\hline $\begin{array}{l}\text { Energy } \\
\text { efficiency } \\
\text { class }\end{array}$ & $\begin{array}{c}\text { Thithuania } \\
\text { (normative) }\end{array}$ & Dukstas & Utena & Vilnius & Panevezys & Siauliai & Kaunas & Klaipeda & Difference\% \\
\hline $\mathrm{C}$ & 80 & 90 & 80 & 80 & 80 & 80 & 80 & 70 & 22.22 \\
\hline $\mathrm{A}$ & 190 & 210 & 200 & 200 & 200 & 190 & 190 & 180 & 14.29 \\
\hline $\mathrm{A}+$ & 240 & 260 & 250 & 250 & 250 & 240 & 240 & 220 & 15.38 \\
\hline $\mathrm{A}++$ & 310 & 330 & 320 & 320 & 310 & 310 & 310 & 280 & 15.15 \\
\hline Difference, $t$ & 3.9 & 3.7 & 4.0 & 4.0 & 3.9 & 3.9 & 3.9 & 4.0 & \\
\hline
\end{tabular}

Table 6. Calculated price of the thermal insulation layer (the initial investment)

\begin{tabular}{|c|c|c|c|c|c|c|c|c|c|}
\hline \multirow{2}{*}{$\begin{array}{l}\text { Energy } \\
\text { efficiency } \\
\text { class }\end{array}$} & \multicolumn{8}{|c|}{ Price of the thermal insulation layer, $€ / \mathrm{m}^{2}$} & \multirow[b]{2}{*}{ Difference $\%$} \\
\hline & $\begin{array}{c}\text { Lithuania } \\
\text { (normative) }\end{array}$ & Dukstas & Utena & Vilnius & Panevezys & Siauliai & Kaunas & Klaipeda & \\
\hline $\mathrm{C}$ & 3.94 & 4.43 & 3.94 & 3.94 & 3.94 & 3.94 & 3.94 & 3.45 & 3.40 \\
\hline A & 9.36 & 10.35 & 9.86 & 9.86 & 9.86 & 9.36 & 9.36 & 8.87 & 5.10 \\
\hline $\mathrm{A}+$ & 11.83 & 12.81 & 12.32 & 12.32 & 12.32 & 11.83 & 11.83 & 10.84 & 6.80 \\
\hline $\mathrm{A}++$ & 15.28 & 16.26 & 15.77 & 15.77 & 15.28 & 15.28 & 15.28 & 13.80 & 8.50 \\
\hline Difference, $t$ & 3.9 & 3.7 & 4.0 & 4.0 & 3.9 & 3.9 & 3.9 & 4.0 & \\
\hline
\end{tabular}

Table 7. Estimated annual savings

\begin{tabular}{|c|c|c|c|c|c|c|c|c|c|}
\hline \multirow{2}{*}{$\begin{array}{l}\text { Energy } \\
\text { efficiency } \\
\text { class }\end{array}$} & \multicolumn{8}{|c|}{ Estimated annual savings, $€ /\left(\mathrm{m}^{2} \cdot\right.$ year $)$} & \multirow{2}{*}{ Difference $\%$} \\
\hline & $\begin{array}{c}\text { Lithuania } \\
\text { (normative) }\end{array}$ & Dukstas & Utena & Vilnius & Panevezys & Siauliai & Kaunas & Klaipeda & \\
\hline $\mathrm{C}$ & 2.82 & 2.82 & 2.61 & 2.61 & 2.59 & 2.65 & 2.58 & 2.30 & 1.80 \\
\hline A & 3.14 & 3.39 & 3.21 & 3.20 & 3.18 & 3.23 & 3.14 & 2.87 & 1.81 \\
\hline $\mathrm{A}+$ & 3.26 & 3.50 & 3.31 & 3.30 & 3.28 & 3.34 & 3.25 & 2.96 & 1.86 \\
\hline $\mathrm{A}++$ & 3.37 & 3.60 & 3.42 & 3.41 & 3.38 & 3.46 & 3.36 & 3.06 & 1.89 \\
\hline Difference, $t$ & 1.3 & 1.3 & 1.3 & 1.3 & 1.3 & 1.3 & 1.3 & 1.3 & \\
\hline
\end{tabular}

Table 8 . The calculated simple payback time

\begin{tabular}{|c|c|c|c|c|c|c|c|c|c|}
\hline \multirow{2}{*}{$\begin{array}{l}\text { Energy } \\
\text { efficiency } \\
\text { class }\end{array}$} & \multicolumn{8}{|c|}{ Simple payback time, years } & \multirow[b]{2}{*}{ Difference $\%$} \\
\hline & $\begin{array}{c}\text { Lithuania } \\
\text { (normative) }\end{array}$ & Dukstas & Utena & Vilnius & Panevezys & Siauliai & Kaunas & Klaipeda & \\
\hline $\mathrm{C}$ & 1.53 & 1.57 & 1.51 & 1.51 & 1.52 & 1.49 & 1.53 & 1.50 & 0.08 \\
\hline A & 2.98 & 3.05 & 3.07 & 3.08 & 3.10 & 2.90 & 2.98 & 3.09 & 0.20 \\
\hline $\mathrm{A}+$ & 3.63 & 3.67 & 3.72 & 3.73 & 3.75 & 3.54 & 3.64 & 3.67 & 0.21 \\
\hline $\mathrm{A}++$ & 4.54 & 4.51 & 4.61 & 4.62 & 4.52 & 4.42 & 4.54 & 4.51 & 0.21 \\
\hline Difference, $t$ & 3.0 & 2.9 & 3.1 & 3.1 & 3.0 & 3.0 & 3.0 & 3.0 & \\
\hline
\end{tabular}

is recommended to use different correlation relationship functions. This is especially relevant for calculating estimates and for performing economic investment calculations.

2. Comparing standard requirements of " $\mathrm{C}$ " energy efficiency class buildings and "A++" class net zero energy buildings, the required thickness of a thermal insulation layer (EPS100) of the typical flooron-soil sample and price increases 4 times, annual savings -1.3 times, and simple payback time -3.1 times up to 4.62 years in the city of Vilnius.
3. Evaluating the same energy efficiency class of the buildings in different climatic zones of Lithuania, it was found that the thinnest thermal insulation layer of partitions touching soil is required in Klaipeda region, while the thickest - Dukstas.

4. The greatest climate fluctuation influence is on buildings with energy efficiency class $\mathrm{A}++$. In this category, the required thickness of a thermal insulation layer (EPS100) pertaining to floor-on-soil varies by $5 \mathrm{~cm}$ between the warmest and the coldest region of Lithuania. 
5. Using personal funds, the payback period may be calculated using the method of simple payback time, without evaluating the change of money in time. According to the research, the payback of contributed funds (the price of thermal insulation materials) is achieved within the period of up to 5 years, regardless of the construction region.

\section{References}

Directive 2010/31/EU of the European Parliament and of the Council of May 192010 on the energy performance of buildings, Official Journal of the European Union L $153 / 13-153 / 35$.

EN ISO 13370:2008 Thermal Performance if Buildings Heat Transfer Via The Ground - Calculation Methods. Brussels: European Committee for Standardization, 2008. $51 \mathrm{p}$.

Kaynakli, O. 2012. A review of the economical and optimum thermal insulation thickness for building applications, Renewable and Sustainable Energy Reviews 16(1): 415-425.

http://dx.doi.org/10.1016/j.rser.2011.08.006

Kong, X.; Lu, S.; Wu, Y. 2012. A review of building energy efficiency in China during "Eleventh Five-Year Plan" period, Energy Policy 41: 624-635. http://dx.doi.org/10.1016/j.enpol.2011.11.024

Kurnitski, J.; Saari, A.; Kalamees, T.; Vuolle, M.; Niemelä, T. 2011. Cost optimal and nearly zero (nZEB) energy performance calculations for residential buildings with REHVA definition for nZEB national implementation, Energy and Buildings 43(11): 3279-3288. http://dx.doi.org/10.1016/j.enbuild.2011.08.033

Statistics Lithuania. 2013. [online], [cited 22 May 2014]. Available on the Internet: http://db1.stat.gov.lt/statbank

Marszal, A. J.; Heiselberg, P.; Jensen, R. L.; Nørgaard, J. 2012. On-site or off-site renewable energy supply options? Life cycle cost analysis of a Net Zero Energy Building in Denmark, Renewable Energy 44: 154-165. http://dx.doi.org/10.1016/j.renene.2012.01.079

RSN 156-94 Building climatology. The Norm on Construction of the Republic of Lithuania. Vilnius, 1994. 22 p.

Stankevičius, V.; Dapkus, G.; Burlingis, A. 1997. Pastatu atitvaru apšiltinimo atsiperkamumas [Insulation payback of building partitions]. Kaunas: ASI. 19 p.

ST 124555837.01:2005 Thermal insulation of building partitions with expanded polystyrene foam. Technical Construction Regulation. Vilnius, 2005.

STR 2.01.09:2012 "Energy performance of buildings. Certification of Energy performance”. Technical Construction Regulation. Vilnius, 2012.

STR 2.05.01:2005 Thermal Technologies of Partitions of a Building. Technical Construction Regulation. Vilnius, 2005.

STR 2.01.03:2009 Declared and Design Values of Thermal Technical Variables of Construction Materials and Products. Technical Construction Regulation. Vilnius, 2009.

The Energy Independence and Security Act of 2007 (EISA). 2007. Public Law 110-140, USA.

Donatas AVIZA. PhD student of the Department of Construction Technology and Management at Vilnius Gediminas Technical University, Vilnius, Lithuania. Master of Science (Civil Engineering), VGTU, 2006. Research interests: building constructions, energy performance of buildings, construction management, multiple criteria analysis and decision making theories.

Zenonas TURSKIS. Prof. Dr of Technical Sciences, Senior Research Fellow at the Laboratory of Construction Technology and Management, Vilnius Gediminas Technical University. Research interests: building technology and management, decision-making theory, computer-aided automation in design, expert systems. 